\title{
Primary production in the upper sea ice
}

\author{
Diane K. Stoecker*, Daniel E. Gustafson, Christine T. Baier **, Megan M. D. Black** \\ Horn Point Laboratory, University of Maryland Center for Environmental Science, PO Box 775, \\ Cambridge, Maryland 21613-0775, USA
}

\begin{abstract}
Observations and experiments were conducted on fast ice in McMurdo Sound, Antarctica, to investigate seasonal changes in primary production in the upper sea ice interior. In November and early December 1995, a dense phytoflagellate assemblage developed in the brine channels and pockets at a snow-free site. Primary production was calculated from ${ }^{14} \mathrm{C}$ measurements of primary productivity in brine samples combined with estimates of the proportion of the ice volume occupied by brine. On 4 December 1995, when the dinoflagellate Polarella glacialis dominated, estimated daily production peaked at $12.4 \mathrm{mg} \mathrm{C} \mathrm{m}^{-2}$ in the upper $50 \mathrm{~cm}$ of ice. On this date, brine temperature was $\sim 3^{\circ} \mathrm{C}$ and brine salinity was -60 . By mid-December, daily production declined by $77 \%$, but chlorophyll-specific rates of photosynthesis remained high. The decline in production coincided with encystment of $P$. glacialis and nutrient depletion, the former triggered by the latter. Primary production continued to decrease during December and January. On 9 January 1996, when ice temperatures were $\sim-1^{\circ} \mathrm{C}$ and brine salinity was -20 , there was a brief bloom of small pennate diatoms in the upper ice interior, but chlorophyll-specific rates of photosynthesis were low and estimated daily production was $<1 \mathrm{mg} \mathrm{C} \mathrm{m}^{-2}$ Based on ${ }^{14} \mathrm{C}$ uptake and brine volume, algal production in the upper $50 \mathrm{~cm}$ of sea ice was $181 \mathrm{mg} \mathrm{C}$ $\mathrm{m}^{-2}$ for the season (mid-November through mid-January). Increases in phytoflagellate biomass in the upper $90 \mathrm{~cm}$ of ice for this same period indicated that production was $\geq 256 \mathrm{mg} \mathrm{C} \mathrm{m}^{-2}$. Brief early season blooms of cryo- and halo-tolerant phytoflagellates accounted for most of the primary production in the upper sea ice interior.
\end{abstract}

KEY WORDS: Sea ice - Antarctica - McMurdo Sound - Ice algae - Cysts - Hypnozygotes - Dinoflagellates - Polarella Diatoms $\cdot$ Chrysophytes - Primary productivity

\section{INTRODUCTION}

At its maximum extent, sea ice is estimated to cover $18 \times 10^{6} \mathrm{~km}^{2}$ in the Antarctic and $14.5 \times 10^{6} \mathrm{~km}^{2}$ in the Arctic, and thus it is an important feature of the world's ocean (Kirst \& Wiencke 1995). Ice algae are estimated to contribute $\sim 20 \%$ of total primary production in both Antarctic and Arctic seas (Kirst \& Wiencke 1995). There have been numerous studies of photosynthesis by microalgae collected from near the base of the sea ice. In contrast there have been relatively few studies

·E-mail: stoecker@hpl.umces.edu

Present addresses:

- National Oceanic and Atmospheric Administration, Alaska Fisheries Science Center, 7600 Sand Point Way NE, Seatthe, Washington 98115, USA

-..National Oceanic and Atmospheric Administration, Southeast Fisheries Center, 101 Pivers Island Rd, Beaufort, North Carolina 28516, USA of photosynthesis by microalgae from the upper sea ice (Garrison \& Buck 1991, Gleitz \& Kirst 1991, Lizotte \& Sullivan 1991, 1992, Fritsen et al. 1994, Archer et al. 1996, Robinson et al. 1997, Stoecker et al. 1997, Mock \& Gradinger 1999).

Microalgae are common in the brine channels and pockets in the interior sea ice in polar seas (Ackley et al. 1979, Garrison \& Buck 1989, 1991, Stoecker et al. 1992, Fritsen et al. 1994, Archer et al. 1996, Mock \& Gradinger 1999). Interior sea ice microalgal assemblages occur in fast ice (sea ice that forms and remains attached to the coast) and pack ice (sea ice that is not attached along the coast). Although internal ice algal assemblages appear to be common in the upper ice, they are not as well documented as the diatom communities that occur near the base of the fast ice (Garrison \& Buck 1989, Watanabe et al. 1990, Syvertsen \& Kristiansen 1993, Archer et al. 1996). This is probably because the diatom assemblages near the base of the 
ice, although they are usually patchy in distribution, have a high biomass with a high chlorophyll content, and thus are of obvious importance. In land-fast ice, the melt pool and interior microalgal assemblages in the upper ice usually have a lower chlorophyll content and biomass per unit ice volume than the diatom-dominated assemblages that occur near the base of the ice. Therefore upper ice assemblages are less noticeable although they may be more widely distributed than the bottom of the ice assemblages (Archer et al. 1996, Mock \& Gradinger 1999).

Estimates of primary production for both the Arctic and Antarctic sea ice (Legendre et al. 1992, Kirst \& Wiencke 1995, Wheeler et al. 1996) suffer from lack of information on the spatial and seasonal extent of various assembiages and their productivity. However, numerical models have been developed to investigate regional differences in primary production in Antarctic pack ice (Arrigo et al. 1997, 1998). The contribution of the upper or interior sea ice assemblages to sea ice primary production has only been documented in a few instances (reviewed in Mock \& Gradinger 1999). In many studies of sea ice primary production, the contribution of interior ice assemblages has not been addressed.

Phytoflagellates are often dominant in the upper sea ice and diatoms in sea ice infiltrated by seawater, particularly at the base of the sea ice (Hsiao 1980, Palmisano \& Sullivan 1983, McConville \& Wetherbee 1983, Garrison \& Buck 1989, 1991, Gradinger et al. 1992, Arrigo et al. 1995, Archer et al. 1996, Ikävalko \& Gradinger 1997, Buck et al. 1998, Stoecker et al. 1998). Phytoflagellate dominance is particularly common early in the growing season when temperatures are well below $-2^{\circ} \mathrm{C}$ and brines are hypersaline. Relatively little is known about the productivity and physiological ecology of sea ice phytoflagellates (Ikävalko \& Gradinger 1997).

The sea ice interior near the ice-air interface is a more extreme environment than the base of the ice and the underlying water column (Kottmeier \& Sullivan 1988, Archer et al. 1996). For example, in McMurdo Sound, Antarctica, interior ice temperatures can be as low as $-20^{\circ} \mathrm{C}$ in the upper $10 \mathrm{~cm}$ of ice at the beginning of the austral spring (late September), with calculated brine volumes $<2 \%$ and brine salinity as high as 220 (Stoecker et al. 1997). During the austral summer (late December and January), upper ice temperatures can reach $-1.5^{\circ} \mathrm{C}$, brine volume may exceed $15 \%$, and the brine within the upper sea ice is usually $<32$ psu (Stoecker et al. 1998). A set of halo- and cryotolerant phytoflagellates grow in the upper fast ice interior in mid- to late November when upper ice temperatures are still below $-4^{\circ} \mathrm{C}$ and brine salinity is elevated (Stoecker et al. 1997, 1998).
In McMurdo Sound fast ice, the dominant phytoflagellates are a small photosynthetic dinoflagellate Polarella glacialis, an ochromonad-like chrysophyte, and a prasinophyte Mantoniella sp. (Stoecker et al. 1992, Montresor et al. 1999). The dinoflagellate and chrysophyte excyst during austral spring, bloom briefly, and then encyst during December and early January (Stoecker et al. 1992, 1997, 1998). Small diatoms bloom in mid- to late December and January in the upper sea ice interior (Stoecker et al. 1998). Similar patterns have been seen in fast ice in East Antarctica (Archer et al. 1996).

Changing light, temperature, brine salinity and nutrient availability probably play important roles in species succession in the upper ice interior. It has been speculated indai nuinient depletion stimiulates sexuality and cyst formation by Polarella glacialis (Stoecker et al. 1998). Life history transitions can be important in species succession. Encystment may be the cause or effect of rapid decreases in primary production (growth) in assemblages dominated by cyst-forming species.

Physical factors (temperature, salinity, light and nutrient availability), as well as biological factors (species composition and abundance, and physiological state), should interact in controlling primary production in the upper sea ice interior as in other aquatic environments. However, because of low diversity in the upper ice, species succession and life history events should be more strongly associated or have a larger impact on primary production in the upper sea ice than these phenomena have in more diverse assemblages in more seasonally stable habitats.

Herein we report on in situ and simulated in situ incubations with brine collected from the interior of first year (less than $1 \mathrm{yr}$ old) fast ice at a snow-free location in McMurdo Sound, Antarctica, between late November 1995 and mid-January 1996 (austral springsummer). Samples were incubated at approximately $30 \mathrm{~cm}$ depth in the ice or under environmental conditions that approximate those at $30 \mathrm{~cm}$ depth in the ice. We manipulated inorganic nutrient concentrations to determine if nutrient depletion triggers cyst formation. Photosynthetic carbon fixation in brine collected from the upper sea ice interior was measured at approximately weekly intervals. We determined physical, chemical and biological parameters for the brine and compared the brine data to similar data obtained from sea ice cores taken at the same location and dates (Stoecker et al. 1998). We used both data sets in interpretation of results from the incubations. Estimates of spring-summer primary production in the upper sea ice interior based on photosynthetic performance and on changes in standing stocks are compared. 


\section{MATERIALS AND METHODS}

Sampling. Brine sampling was carried out in conjunction with a seasonal study of micro-environmental conditions and algal population dynamics in the upper land-fast sea ice at a windswept, snow-free area on the annual sea ice just north of Inaccessible Island in McMurdo Sound, Antarctica ( $77^{\circ} 39.18^{\prime} \mathrm{S}, 166^{\circ} 25.67^{\prime} \mathrm{E}$ ). At approximately weekly intervals between midNovember 1995 and mid-January 1996, triplicate coring sites were randomly chosen within the approximately $10000 \mathrm{~m}^{2}$ study area, and $90 \mathrm{~cm}$ cores were obtained at each of the sites using a Sipre corer (Rand \& Mellor 1985, Stoecker et al. 1998). Core holes were covered with small pieces of plywood, and brine was allowed to accumulate. Brine was collected after the brine level in a hole had become stable. Brine samples were transported in coolers to the laboratory for chemical and biological analyses.

Determination of environmental parameters. The depth of brine from the ice surface was measured with a meter stick and in situ temperature of brine was measured with a digital thermometer. A Li-Cor 193SB spherical sensor was used to measure irradiance at the surface of the ice and just below the brine surface in the core holes with covers in place. Most of the irradiance in the ice is diffuse; thus use of small covers during the measurements, to exclude direct light from reaching the probe, works well.

In the laboratory, salinity of collected brine samples was determined using a YSI (Yellow Springs Instrument Co.) salinometer (some samples were diluted with distilled water for measurement). Duplicate subsamples from each brine sample were stored frozen for nutrient analyses (Lachat QuikChem AE Autoanlyzer). Standard addition experiments were performed to determine if the high brine salinity interfered with the nutrient analyses; when necessary, samples were diluted with Milli-Q water prior to analysis. Duplicate subsamples were filtered onto GF/F Whatman glass fiber filters, extracted in $90 \%$ acetone with grinding and chlorophyll a (chl a) determined by fluorometry (Parsons et al. 1984).

Microscopic analysis of microalgal assemblages. To enumerate microalgae, subsamples of brine were fixed and preserved with $1 \%$ glutaraldehyde. The fixed samples were stained with proflavine and examined using epifluorescence microscopy (Stoecker et al. 1992). Chlorophyll-containing cells and cysts were enumerated and cysts were distinguished from vegetative cells by the penetration of proflavine into vegetative cells but not into cysts as well as by differences in morphology.

Cyst formation experiments. Two experiments were performed to determine if addition of inorganic nutrients would affect cyst formation by Polarella glacialis and chrysoflagellates. On 2 dates in December, approximately $600 \mathrm{ml}$ brine samples were collected from core holes at the Inaccessible Island site. At the time of collection, in situ brine temperature was measured with a digital thermometer and subsamples were taken for determination of brine salinity and for microscopic analyses. The brine samples were transported in a cooler to a site on the fast ice closer to McMurdo Station (the Hut site, Stoecker et al. 1997), where experimental manipulations were done.

For each experiment, duplicate control and +nutrient flasks were employed. We gently dispensed $100 \mathrm{ml}$ of brine into each of four $250 \mathrm{ml}$ polycarbonate screwcap flasks. Nitrate $(0.1 \mathrm{ml}$ of a stock solution of $7.5 \%$ $[\mathrm{w} / \mathrm{v}] \mathrm{NaNO}_{3}$ in distilled water) and phosphate $(0.1 \mathrm{ml}$ of a stock solution of $0.5 \%[\mathrm{w} / \mathrm{v}] \mathrm{NaH}_{2} \mathrm{PO}_{4} \cdot \mathrm{H}_{2} \mathrm{O}$ in distilled water) were added to the + nutrient flasks to achieve added concentrations of $883 \mu \mathrm{M}$ nitrate and $36 \mu \mathrm{M}$ phosphate. The control flasks were not amended. The experimental and control flasks were incubated together in brine in covered core holes at the Hut site. Light levels during incubation were approximately $33 \%$ of surface incident irradiance. Temperature in the incubation holes was measured each time the bottles were sampled. For the first incubation, the bottles were retrieved at approximately weekly intervals and $20 \mathrm{ml}$ subsamples were removed for microscopic analyses before the bottles were replaced in the holes. In the second experiment, the bottles were sampled after 4 and $13 \mathrm{~d}$. Both experiments were ended on 27 December.

For statistical analyses, a square-root transformation was applied to counts and an arcsine transformation was applied to proportions (Sokal \& Rohlf 1995). The difference between treatments was tested for statistical significance with a 2 -tailed $t$-test with equal variances unless the variances were unequal, then a 2 -tailed $t$-test with unequal variances was employed (Sokal \& Rohlf 1995). Statistical analyses were carried out using Jandel SigmaStat version 2.0 .

Photosynthesis experiments. Photosynthesis by upper sea ice microalgae was investigated by measuring ${ }^{14} \mathrm{C}$ uptake by brine samples collected from core holes in the ice and incubated at a range of irradiances under in situ or simulated in situ conditions for $-24 \mathrm{~h}$. We chose $1 \mathrm{~d}$ field incubations over short-term laboratory measurements because our objective was to estimate primary production in the upper ice. Short-term laboratory measurements are good for measuring physiological responses of microalgae, but they do not necessarily extrapolate accurately to daily in situ production (Henley 1993).

Approximately $2 \mathrm{l}$ of brine were collected for each experiment, then transported in a cooler to a site where incubations could be conducted. A hut or tent 
on the land-fast ice at the Hut site (Stoecker et al. 1997) was used during November and December to set up the incubation bottles, but by January it was no longer possible to access the Hut site because of surface ice decay. In January, the incubations were set up in the Crary Laboratory at McMurdo Station.

${ }^{14} \mathrm{C}$ bicarbonate $\left(57.3 \mathrm{mBq} \mathrm{mmol}^{-1}\right)$ was added to $1400 \mathrm{ml}$ of the brine to achieve activities of $-0.1 \mathrm{mBq}$ $\mathrm{ml}^{-1}$. Aliquots $(100 \mathrm{ml})$ of the spiked brine were dispensed under low light conditions into duplicate Teflon bottles with 0 to 5 layers of screening, which transmitted 92 to $3 \%$ of photosynthetically active radiance (PAR). Duplicate black Teflon bottles were used as dark controls. The remaining $600 \mathrm{ml}$ of brine was used for determination of dissolved inorganic carbon (DIC) (í iviodel 700 Carbon analyzer), salinity, chl $a$, and for enumeration of microalgae.

Because of the snow cover and ice thickness at the hut site, the upper ice temperatures and light levels during late November and early December were much lower than at the snow-free Inaccessible Island site (Stoecker et al. 1997, 1998). We chose not to incubate the bottles directly in the ice. Instead we immersed the incubation bottles in a water-filled translucent fiberglass tub sunk in the sea ice; sodium chloride was added to the tub to keep the bottles from freezing-in, which facilitated their retrieval. During late November and early December, the temperatures in the tub were close to the ice temperatures at the Inaccessible Island site, but by 14 December the temperatures in the tub were higher than in the upper ice at the Inaccessible Island site. On 19 December we switched to incubating the bottles in an uncovered core hole. By the beginning of January, it was no longer possible to get to the hut site, so incubations were performed in an outdoor flowing seawater incubator at McMurdo Station. By this time, surface ice temperatures were close to seawater temperature. In all cases, the experiments were set up within 2 to $3 \mathrm{~h}$ of brine collection.

Incubation temperatures were measured with a digital thermometer at the beginning and end of incubation. Surface irradiance and irradiance in the brine or seawater surrounding the incubation bottles were measured with a Li-Cor $193 \mathrm{SB}$ spherical quantum sensor; from these data, percent incident irradiance reaching the surface of the bottles was calculated. For each experiment, average surface PAR was modeled from hourly 400 to $600 \mathrm{~nm}$ radiance $\left(\mu \mathrm{W} \mathrm{cm}^{-2}\right)$ measured at McMurdo Station by Biospherical Instruments, Inc. To obtain average surface PAR during an experiment, average $\mu \mathrm{W} \mathrm{cm} \mathrm{cm}^{-2}$ radiance $(400$ to $600 \mathrm{~nm}$ ) was PAR corrected and then converted to $\mu \mathrm{mol}$ photons $\mathrm{m}^{-2} \mathrm{~s}^{-1}$. Percent incident irradiance for each treatment was calculated as the product of percent incident irradiance reaching the surface of the incubation bottles and the $\%$ transmittance of the treatment bottles, which ranged from 92 to $3 \%$ of PAR for the light treatments. Average PAR for a treatment was calculated as percent incident irradiance for the treatment multiplied by average surface PAR for the incubation.

After incubation for $\sim 24 \mathrm{~h}$, the bottles were retrieved and transported in insulated chests to the laboratory. To measure total activity (TA) of ${ }^{14} \mathrm{C}, 100 \mu \mathrm{l}$ of brine was added to a scintillation vial containing $100 \mu \mathrm{l}$ of phenylethylamine and then $7 \mathrm{ml}$ of scintillation cocktail (Ecolume, ICN Biochemicals, Inc.) was added. Triplicate samples were taken. The samples were counted on a Beckman LS 6800 liquid scintillation counter with automatic quench correction. The TA $\left(\mathrm{dpm} \mathrm{ml} \mathrm{m}^{-1}\right.$ ) was calculated as average dpm in the $100 \mu \mathrm{l}$ samples multiplied by 10 Fixer ${ }^{14} \mathrm{C}$. was measured on duplicate $50 \mathrm{ml}$ samples from each incubation bottle. In very low light, each $50 \mathrm{ml}$ sample was filtered ( $<25 \mathrm{~mm} \mathrm{Hg}$ pressure) onto a $2.5 \mathrm{~cm}$ diameter Whatman GF/F filter, the filter was placed in a scintillation vial and dampened with $10 \% \mathrm{HCl}$ to kill the cells and remove residual ${ }^{14} \mathrm{C}$ bicarbonate. The filters were dried at $60^{\circ} \mathrm{C}$ in a hood and then $1 \mathrm{ml}$ of distilled water and $7 \mathrm{ml}$ Ecolume were added. The activity on the filters was measured with a Beckman LS 6800 liquid scintillation counter with automatic quench correction.

For each light bottle, the carbon fixed was calculated as:

$$
\mu \mathrm{C}^{-1} \mathrm{~d}^{-1}=\left(R_{\mathrm{x}}-R_{\mathrm{d}}\right) \times 20 \times(\mathrm{DIC} / \mathrm{TA}) \times 1.05
$$

where $R_{\mathrm{x}}$ is the average dpm for the light bottle $(50 \mathrm{ml}$ filtered sample), $R_{\mathrm{d}}$ is the average dpm for the dark bottles (50 $\mathrm{ml}$ filtered samples), DIC is the dissolved inorganic carbon ( $\mu \mathrm{g} \mathrm{m}^{-1}$ ), TA is the total activity (dpm $\mathrm{ml}^{-1}$ ) and 1.05 is the isotope discrimination factor for ${ }^{14} \mathrm{C}$ (Welschmeyer \& Lorenzen 1984).

The photosynthesis-irradiance $(P-I)$ data were fitted to a hyperbolic tangent function (Jassby \& Platt 1976) using commercial software (SigmaPlot version 4.0, Jandel Scientific).

Standard errors for estimates of maximum rate of photosynthesis $\left(P_{\max }\right)$ and initial slope of the photosynthesis versus irradiance curve $(\alpha)$ were determined by the fitting algorithm.

\section{RESULTS}

\section{Environmental conditions}

The physical and chemical properties of the collected brine changed dramatically due to warming between late November and mid-December 1995, and then remained relatively constant between late December and mid-January 1996 (Table 1). The last sam- 
Table 1. Physical-chemical conditions in brine collected from triplicate core holes at the Inaccessible Island study site. Mean \pm standard error. NS = no sample collected

\begin{tabular}{|c|c|c|c|c|c|c|c|}
\hline Date & $\begin{array}{l}\text { Temp. } \\
\left({ }^{\circ} \mathrm{C}\right)\end{array}$ & Salinity & $\begin{array}{c}\text { Chl } a \\
\left(\mu \mathrm{g} \mathrm{l}^{-1}\right)\end{array}$ & $\begin{array}{l}\mathrm{NH}_{4} \\
(\mu \mathrm{M})\end{array}$ & $\begin{array}{c}\mathrm{NO}_{2}+\mathrm{NO}_{3} \\
(\mu \mathrm{M})\end{array}$ & $\begin{array}{l}\mathrm{PO}_{4} \\
(\mu \mathrm{M})\end{array}$ & $\begin{array}{c}\text { Brine vol } \\
(\%)\end{array}$ \\
\hline 27 Nov 95 & $-4.4 \pm 0.3$ & $82.2 \pm 4.7$ & $10.0 \pm 3.0$ & NS & NS & NS & 10.7 \\
\hline 4 Dec 95 & $-3.2 \pm 0.03$ & $60.5 \pm 2.3$ & 7.04 & $0.83 \pm 0.02$ & $5.84 \pm 0.9$ & $2.09 \pm 0.6$ & 11.4 \\
\hline 14 Dec 95 & $-2.2 \pm 0.1$ & $38.4 \pm 0.5$ & $0.76 \pm 0.07$ & $0.41 \pm 0.3$ & $0.93 \pm 0.1$ & $0.13 \pm 0.0$ & 17.8 \\
\hline 19 Dec 95 & $-1.9 \pm 0.06$ & $32.7 \pm 0.9$ & $0.95 \pm 0.06$ & $1.43 \pm 0.6$ & $0.70 \pm 0.2$ & $0.13 \pm 0.01$ & 14.7 \\
\hline 27 Dec 95 & $-1.6 \pm 0.03$ & $25.5 \pm 1.7$ & $0.26 \pm 0.04$ & $1.07 \pm 0.2$ & $0.28 \pm 0.14$ & $0.03 \pm 0.0$ & 17.3 \\
\hline $4 \operatorname{Jan} 96$ & $-1.4 \pm 0.03$ & $22.3 \pm 0.7$ & $0.29 \pm 0.2$ & $0.58 \pm 0.2$ & $0.17 \pm 0.03$ & $0.33 \pm 0.1$ & 13.4 \\
\hline $9 \operatorname{Jan} 96$ & $-1.4 \pm 0.07$ & $20.4 \pm 0.2$ & $0.69 \pm 0.5$ & $0.21 \pm 0.11$ & $0.33 \pm 0.05$ & $0.19 \pm 0.02$ & 17.0 \\
\hline 17 Jan 96 & $-1.6 \pm 0.03$ & $24.8 \pm 0.1$ & $0.06 \pm 0.02$ & $0.59 \pm 0.5$ & $0.40 \pm 0.06$ & $0.21 \pm 0.03$ & 14.8 \\
\hline
\end{tabular}

ple was taken on 17 January and the ice at this location broke out between 20 and 22 January 1996.

Between 27 November and 14 December 1995, the brine collected from the core holes was hypersaline compared to seawater, and brine temperatures were below $-2^{\circ} \mathrm{C}$ (Table 1 ). On 19 December, brine salinity was near 32 and brine temperature was around $-2^{\circ} \mathrm{C}$. Between the end of December and the last sampling on 17 January 1996, the brine was hyposaline compared to seawater, and brine temperatures were between -1.7 and $-1.3^{\circ} \mathrm{C}$. The lowest brine salinity $(\sim 20)$ and one of the highest brine temperatures $\left(\sim-1.4^{\circ} \mathrm{C}\right)$ occurred in the 9 January samples.

Concentrations of nitrate and inorganic phosphate were low in brine samples collected after mid-December (Table 1). Ammonium concentrations were relatively high $(>1 \mu \mathrm{M})$ in some samples, and variability among samples collected from replicate core holes was high (Table 1). Chl a concentrations were highest in the November samples and mostly $<1 \mu \mathrm{g} \mathrm{l}^{-1}$ from midDecember onward (Table 1).

\section{Abundance and composition of brine microalgal assemblage}

Flagellated cells of photosynthetic chrysophytes were numerically dominant in the hypersaline brines collected in late November and early December, occurring at densities of $\geq 10^{7}$ cells $\mathrm{l}^{-1}$, but were rare in brines collected after 4 December (Table 2). However, coccoid chrysophyte cells were abundant in brine samples collected in mid-December when brine temperatures were between -2.4 and $-1.8^{\circ} \mathrm{C}$ and brine salinity was between $\sim 32$ and 39 (Tables 1 \& 2). Chrysophyte statocysts were detectable in brine from mid-December onward, and their densities in the brine peaked in late December and January (Table 2).

The dominant photosynthetic dinoflagellate in the brine was a small gymnodinioid species, which has been recently described as Polarella glacialis gen. nov., sp. nov. (Montresor et al. 1999). It occurred at densities $>10^{6} \mathrm{l}^{-1}$ of brine between late November and early January (Table 2). Flagellated cells of this species

Table 2. Abundance of microalgae in brine collected from triplicate core holes at the Inaccessible Island site. Mean numbers of cells $\times 10^{3} \mathrm{l}^{-1} \pm$ standard error. $\mathrm{ND}=$ not detectable

\begin{tabular}{|c|c|c|c|c|c|c|c|c|c|}
\hline \multirow{2}{*}{ Date } & \multirow[b]{2}{*}{ Flagellates } & \multirow{2}{*}{$\begin{array}{l}\text { Chrysophytes } \\
\text { Coccoid } \\
\text { cells }\end{array}$} & \multirow[b]{2}{*}{ Statocysts } & \multirow[b]{2}{*}{$\begin{array}{l}\text { Polarella } \\
\text { glacialis }\end{array}$} & \multirow{2}{*}{$\begin{array}{c}\text { Dinoflagellates } \\
\text { Larger } \\
\text { dinoflagellate }\end{array}$} & \multirow[b]{2}{*}{ Cysts } & \multirow{2}{*}{ Mantoniella sp. } & \multirow{2}{*}{ Diatoms } & \multirow{2}{*}{ Others } \\
\hline & & & & & & & & & \\
\hline 27 Nov 95 & $11324 \pm 3408$ & ND & ND & $1797 \pm 389$ & $142 \pm 33.5$ & ND & $999 \pm 589$ & ND & $250 \pm 250$ \\
\hline $4 \operatorname{Dec} 95^{\circ}$ & 10084 & ND & ND & 10313 & ND & ND & ND & ND & ND \\
\hline 14. Dec 95 & ND & $3893 \pm 994$ & $26 \pm 27$ & $4978 \pm 943$ & $27 \pm 27$ & $728 \pm 85$ & $5458 \pm 3047$ & ND & ND \\
\hline $19 \operatorname{Dec} 95$ & ND & $5190 \pm 1815$ & $714 \pm 369$ & $4450 \pm 1703$ & $48 \pm 48$ & $1172 \pm 345$ & $6720 \pm 6189$ & ND & ND \\
\hline 27 Dec 95 & ND & $650 \pm 232$ & $4764 \pm 1877$ & $1707 \pm 279$ & ND & $24801 \pm 546$ & $506 \pm 310$ & $24 \pm 24$ & ND \\
\hline 4 Jan 96 & ND & $388 \pm 161$ & $3601 \pm 579$ & $1364 \pm 243$ & ND & $1950 \pm 283$ & $1277 \pm 1088$ & $111 \pm 60$ & $664 \pm 62$ \\
\hline $9 \operatorname{Jan} 96$ & ND & $240 \pm 191$ & $1847 \pm 1114$ & $123 \pm 45$ & ND & $1361 \pm 520$ & $2161 \pm 64.4$ & $735 \pm 382$ & $421 \pm 47$ \\
\hline $17 \operatorname{Jan} 96$ & ND & $178 \pm 67$ & $5941 \pm 596$ & $141 \pm 47$ & ND & $1256 \pm 467$ & $891 \pm 743$ & $19 \pm 18$ & $284 \pm 144$ \\
\hline
\end{tabular}


occurred only at low densities in the brine after 4 January. The resting cysts (hypnozygotes) of $P$. glacialis were not detectable in the brine until mid-December but they occurred at high densities from mid-December until the end of the sampling season. A larger, mixotrophic dinoflagellate was also detected (refer to Fig. 4b in Stoecker et al. 1992), but it was much rarer than $P$. glacialis (Table 2).

Other microalgae found in the brine included the small flagellated prasinophyte Mantoniella sp. and a mixture of small pennate diatoms (Table 2). Mantoniella sp. occurred at high densities in some brine samples throughout the sampling season. Diatoms were not detectable in the brine until late December, and diatom densites were low in the brine except in saminples collected on 9 Jañuariny.

\section{Cyst formation}

The first nutrient addition incubation was started on 4 December, with brine of a salinity of 65 and a temperature, at the time of collection, of $-3.3^{\circ} \mathrm{C}$. The brine contained vegetative cells of the dinoflagellate Polarella glacialis $\left(\sim 2.8 \times 10^{4} \mathrm{ml}^{-1}\right)$ and chrysoflagellates $(\sim 9 \times$ $\left.10^{3} \mathrm{ml}^{-1}\right)$. No dinoflagellate or chrysophyte cysts were found. The brine temperature during the $23 \mathrm{~d}$ incubation at the Hut site ranged from -3.4 to $-2.0^{\circ} \mathrm{C}$ and irradiance was $\sim 33 \%$ of incident surface irradiance.

During the first week of the incubation, dinoflagellate numbers increased in both control and nutrient addition treatments (Fig. 1A). By 18 December, some of the dinoflagellates in the control treatment had a 'bubbly' surface texture, which often precedes cyst formation. On 27 December, $>94 \%$ of the dinoflagellate cells in the control treatment were encysted, but none of the dinoflagellate cells in the nutrient addition treatment were encysted (Fig. 1B). At the end of the experiment, the percent of the dinoflagellates which were cysts was significantly higher in the control than in the nutrient addition treatment ( $p<0.05$ ).

After the initial sample, it was not possible to enumerate chrysoflagellates because the samples were not filtered immediately after fixation, and the chrysoflagellate autofluorescence faded in the later samples. However, the chrysophyte statocysts were readily distinguishable. Statocysts were observed in both the control and experimental treatments on 18 December. By the end of the incubation on 27 December, statocysts were present at mean densities of 1.1 to $1.7 \times 10^{3}$ cells $\mathrm{ml}^{-1}$. The difference in abundance of statocysts between treatments was insignificant ( $p>0.05$ ) (Fig. 2A).
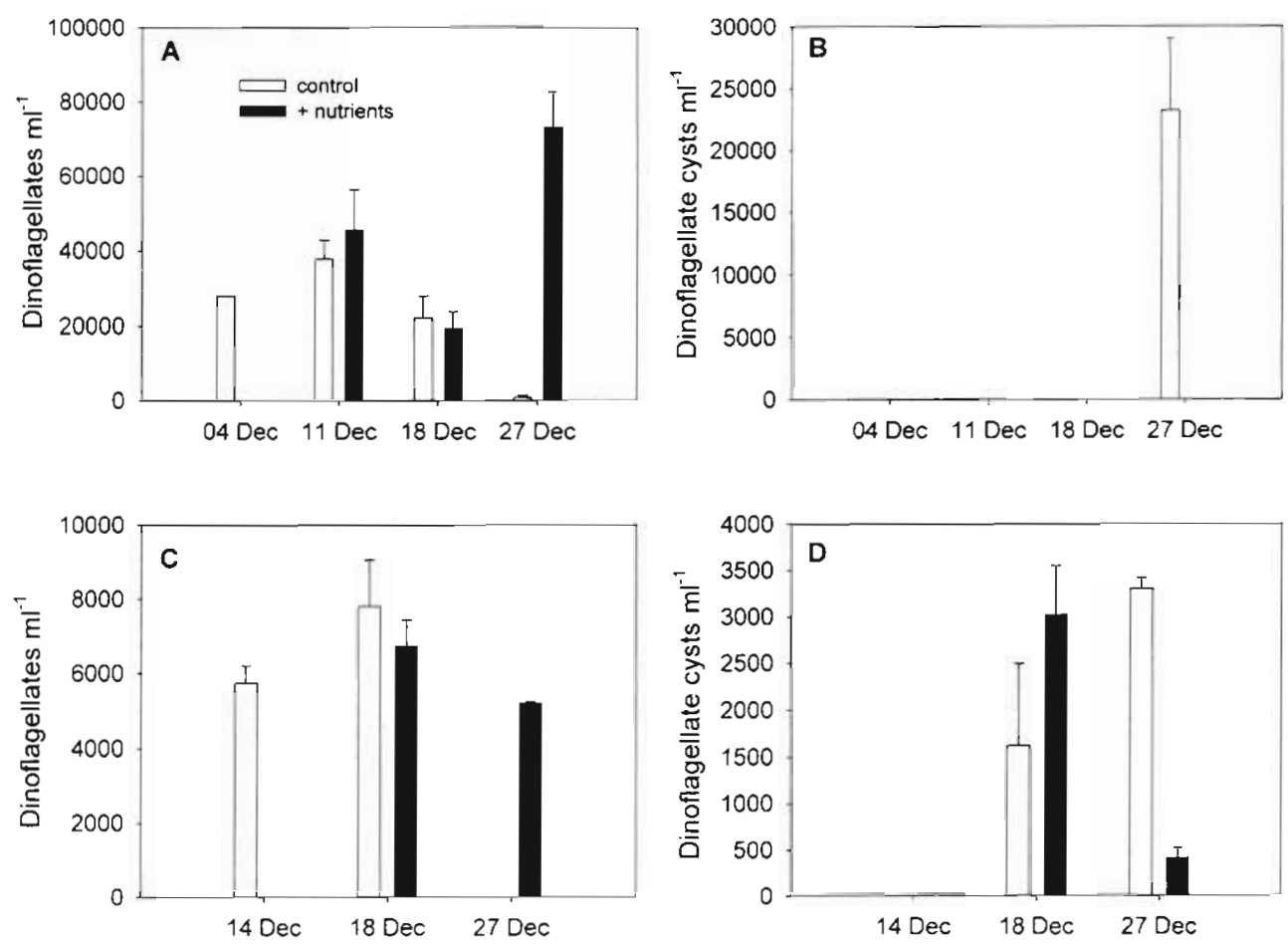

Fig. 1. Polarella glacialis. Abundance of $(A, C)$ vegetative cells and $(B, D)$ resting cysts (hypnozygotes) during in situ incubations with brine collected on 4 and on 14 December 1995. $N=2$ except for initial densities on 4 and 14 December for which $N=1$. Means + standard error 

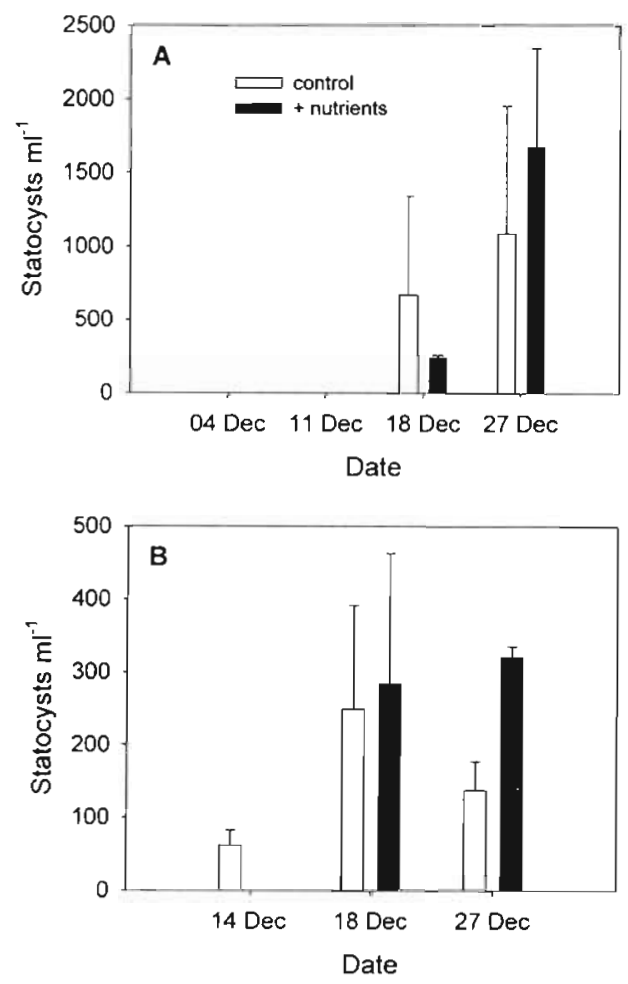

Fig. 2. Abundances of chrysophyte statocysts during in situ incubations with brine collected on (A) 4 December and (B) 14 December 1995. $N=2$ except for initial densities on 4 and 14 December for which $N=1$. Means + standard error

In the second nutrient addition incubation, which was started $10 \mathrm{~d}$ later than the first, brine salinity was 37 and brine temperature at the time of collection was $-2.4^{\circ} \mathrm{C}$. Initial densities of vegetative cells of dinoflagellates and chrysoflagellates were both $\sim 6 \times 10^{3}$ cells $\mathrm{ml}^{-1}$ (Figs. 1C \& 2B). In contrast to the first experiment, dinoflagellate cells with a 'bubbly' texture were evident at the beginning, indicating the initiation of cyst formation. Low numbers of statocysts were also present (Fig. 2B). Four days later, dinoflagellate cysts were present in both control and nutrient addition treatments at about equal numbers (Fig. 1D) with the difference in percent cysts not significantly different $(p>0.05)$. At the end of the first incubation, dinoflagellate vegetative cells were low in abundance and cysts were abundant in controls, but in the nutrient addition treatment the number of dinoflagellate vegetative cells had risen and the number of cysts was low (Fig. 1 C,D). The percent of dinoflagellates which were encysted was significantly higher in the control than in the nutrient addition treatment $(p<0.01)$. The number of statocysts increased in both treatments. The average number of statocysts was higher in the nutrient addition treatment (Fig. 2B), but the difference between treatments was not statistically significant $(\mathrm{p}>0.05)$.

\section{Photosynthesis and primary production}

Initial temperature and salinity of brine samples used in the incubations (Table 3 ) were close to average values for the site sampled on the same day (Table 1). On 14 December, the incubation temperature at the Hut site was 1.1 to $2.1^{\circ} \mathrm{C}$ warmer than in the upper ice at the sampling site (Table 3). From 19 December to 17 January, incubation temperatures were only slightly warmer $\left(<1^{\circ} \mathrm{C}\right)$ than in the upper ice at Inaccessible Island (Table 3).

At the sampling site near Inaccessible Island, PAR just below the brine surface in core holes (about 20 to $30 \mathrm{~cm}$ from ice surface) averaged 248 to $498 \mu \mathrm{mol}$ photons $\mathrm{m}^{-2} \mathrm{~s}^{-1}$. This was $22 \%(\mathrm{n}=8$, range 17 to $31 \%$ ) of the incident PAR at the ice surface around mid-day (Table 3). In the incubations done in the tub at the Hut site, light levels were lower than in brine at the sampling site, with only $6.9 \%$ of incident PAR reaching the unscreened treatments in the 30 November and 4 December experiments, and $9.25 \%$ in the 14 December experiment (Table 3). In the 19 December incubation, which was conducted in a core hole, the calculated irradiance for an unscreened bottle was $-27.6 \%$ of incident PAR and thus was within the in situ range at the sampling site. In the January incubations, which were conducted in a flowing seawater incubator, the unscreened treatments were exposed to $\sim 32.2 \%$ incident PAR, which was slightly higher than the range observed in situ. Average PAR at the ice surface $\left(I_{0}\right)$ during the incubations ranged from 548 to $722 \mu \mathrm{mol}$ photons $\mathrm{m}^{-2} \mathrm{~s}^{-1}$ (Table 3).

Average chl a values in the brine were relatively high, 7.0 and $7.5 \mathrm{~kg} \mathrm{l}^{-1}$, in the first 2 incubations, but chlorophyll values were $<1 \mathrm{\mu g} \mathrm{l}^{-1}$ in the other incubations except for the 9 January incubation when the brine had $1.64 \mu \mathrm{g} \mathrm{chl} \mathrm{a} \mathrm{l}^{-1}$. In the first 2 incubations, light saturation was not evident (Fig. 3 A,B) and thus the maximum rate of photosynthesis $\left(P_{\max }\right.$ and chl $a$ specific $P_{\max }$ ) is a minimum estimate (Table 3). However, rates of photosynthesis in the unscreened treatments were high, 72 and $218 \mu \mathrm{g} \mathrm{Cl}^{-1}$ of brine $\mathrm{d}^{-1}$, on 30 November and 4 December, respectively (Table 3). For the other incubations, light saturation occurred and there was no evidence of photoinhibition (Figs. 3 \& 4). Between 14 December and 17 January, $P_{\max }$ declined from 32 to $5 \mu \mathrm{g} \mathrm{C} \mathrm{I}^{-1}$ of brine $\mathrm{d}^{-1}$. Chl a-specific $P_{\max }$ declined from $1.5 \mu \mathrm{g} \mathrm{C}(\mu \mathrm{g} \mathrm{chl} a)^{-1} \mathrm{~h}^{-1}$ on 14 December to $<1.0$ during the rest of the sampling period (Table 3). The light adaption index $\left(I_{k}\right)$ was calculated as $P_{\max }$ divided by $\alpha$, the initial slope of the photosynthesis versus irradiance curve (Table 3 ). $I_{k}$ values ranged from 11 to $48 \mu \mathrm{mol}$ photons $\mathrm{m}^{-2} \mathrm{~s}^{-1}$ (Table 3 ).

Experimentally measured $I_{k}$ values were consistently lower than irradiance measured around mid-day in brine at 20 to $30 \mathrm{~cm}$ down from the ice surface at the 
Table 3. Photosynthesis versus irradiance incubations with brine from the Inaccessible Island site. Photosynthetic parameters are determined from fitting data to the equation of Jassby \& Platt (1976). T = tub in ice at the Hut site; $\mathrm{H}=$ uncovered core hole at the Hut site; $\mathrm{I}=$ flowing seawater incubator at McMurdo Station. Avg $I_{0}=$ Average irradiances at the ice surface during the $\sim 24 \mathrm{~h}$ incubations. At the time of brine collection (10:00 to 12:30 h), the in situ irradiance just below the brine level in the sea-ice at the Inaccessible Island site ranged from 248 to $498 \mu \mathrm{mol}$ photons $\mathrm{m}^{-2} \mathrm{~s}^{-1}(17$ to $31 \%$ the irradiance at the ice surface) ( $\mathrm{N}=8$ ). Average irradiances for the treatments during the incubations are given in the $P$-I curves (Figs. $3 \& 4$ )

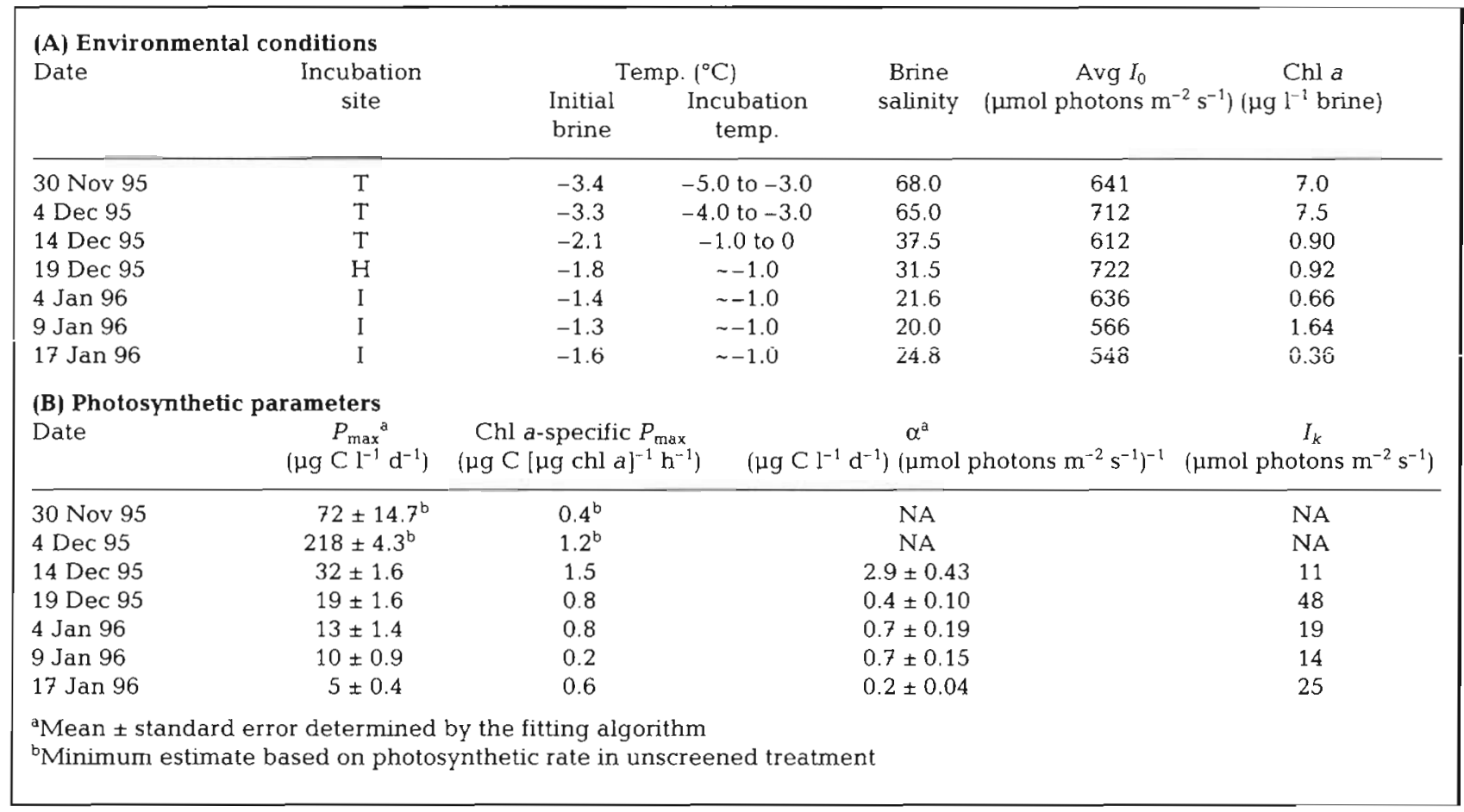

snow-free Inaccessible Island site (Table 3). Thus, we took $P_{\max }$ as an estimate of photosynthetic performance in brine in the upper $50 \mathrm{~cm}$ of ice. Daily primary production ( $\mathrm{mg} \mathrm{C} \mathrm{m}^{-2}$ ) in the upper $50 \mathrm{~cm}$ of sea ice was calculated as:

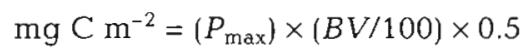

where $B V$ is \% brine volume from Table 1.

Estimated daily primary production ranged from a high of $\sim 12 \mathrm{mg} \mathrm{C} \mathrm{m}^{-2}$ on 4 December 1995 to a low of $0.4 \mathrm{mg} \mathrm{C} \mathrm{m}^{-2}$ on 17 January 1996 (Fig. 5). The highest production took place in early December during a bloom of the dinoflagellate Polarella glacialis. Within $10 \mathrm{~d}$, daily production dropped by $77 \%$ as the dinoflagellate encysted and as inorganic nutrients declined to low levels (Fig. 5, Tables 1 \& 2). In January (austral summer), when diatoms were present in the upper ice and temperatures and brine volumes were relatively high (Tables $1 \& 2$ ), daily primary production was $<1 \mathrm{mg} \mathrm{C} \mathrm{m}^{-2}$.

\section{DISCUSSION}

Sea ice consists of a complex matrix of ice and brine, with brine volume dependent on temperature and sea ice salinity (Weeks \& Ackley 1982, Maykut 1985, Weissenberger et al. 1992, Ackley \& Sullivan 1994). With current techniques, it is not feasible to measure photosynthetic rates with intact sea ice, although experiments have been performed with sectioned cores (Mock \& Gradinger 1999). Melting cores to release microalgae drastically changes the physical and chemical milieu to which the microalgae are exposed. For these reasons, we chose to collect brine from core holes and use it for ${ }^{14} \mathrm{C}$ uptake incubations to measure photosynthesis. This minimized damage to algal cells and changes in their chemical environment.

However, the brine that accumulates in core holes probably differs from the average brine in intact sea ice (Stoecker et al. 1997). The species composition of algae in collected brine often differs from that in ice cores. Early in the season, chrysoflagellate biomass in brine was higher than in ice cores (Table 4). In contrast, the coccoid, non-motile, chrysophyte life history stages were more abundant in cores than in brine (Table 4). Similar differences between brine and cores in the distribution of chrysophytes were observed at a snow-covered site on the sea ice (Stoecker et al. 1997). Flagellated stages of Polarella glacialis and the prasin- 

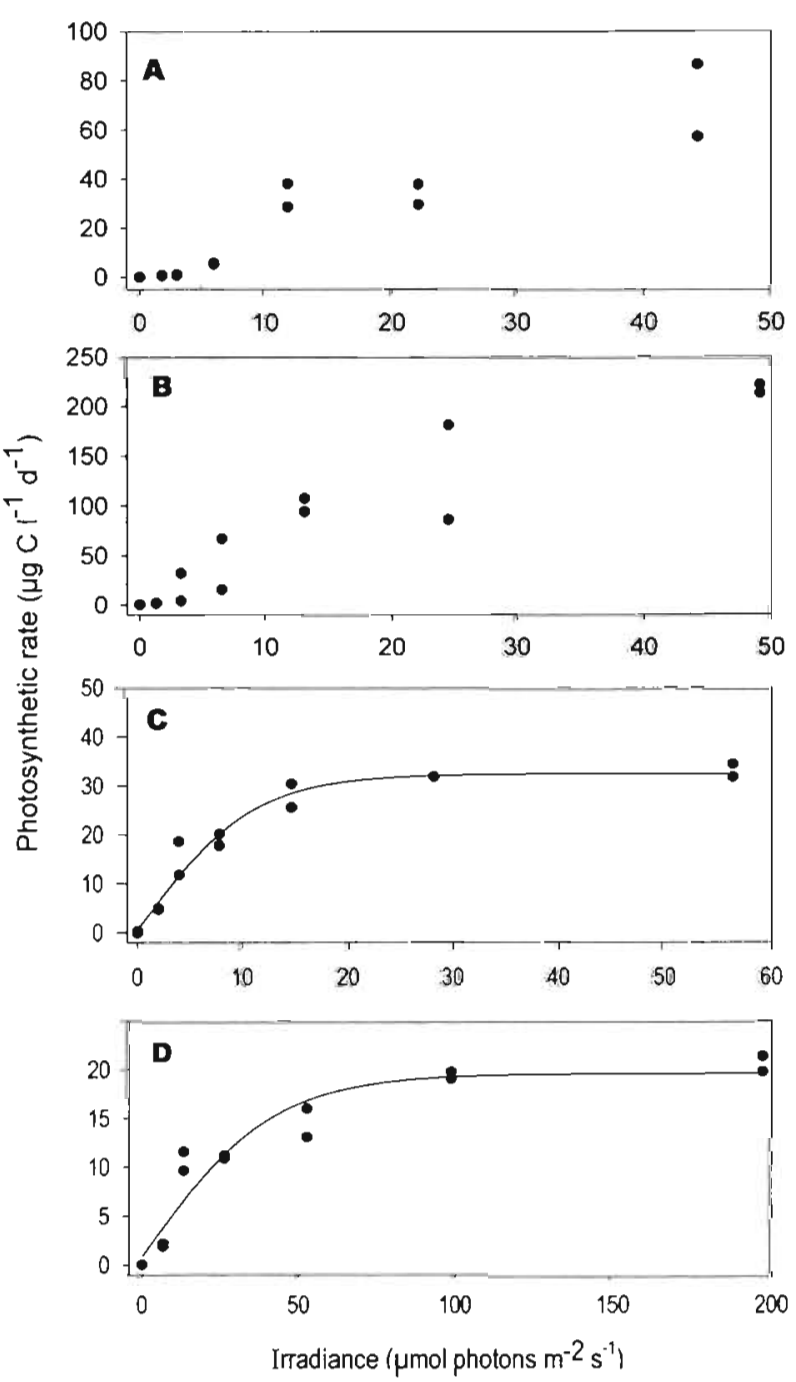

Fig. 3. Daily photosynthesis versus irradiance for in situ and simulated in situ brine incubations started on (A) 30 November, (B) 4 December, (C) 14 December, and (D) 19 December 1995. Curve fitting with hyperbolic tangent function (Jassby \& Platt 1976)

ophyte Mantionella sp. were usually more abundant in brine than in ice cores (Table 4). Cyst formation was evident at the same time in both ice cores (Stoecker et al. 1998) and brine samples (Table 2). The brine obtained from core holes should best represent the ice depths with the greatest brine volume, between 25 and $55 \mathrm{~cm}$ in our investigation (Table 1c in Stoecker et al. 1998).

Although there are obvious differences between cores and brine, measurement of chl a and photosynthesis using brine assemblages, in concert with physical and chemical data, can provide useful information on seasonal changes in primary production in the upper sea ice. Chl a values in the brine peaked in late
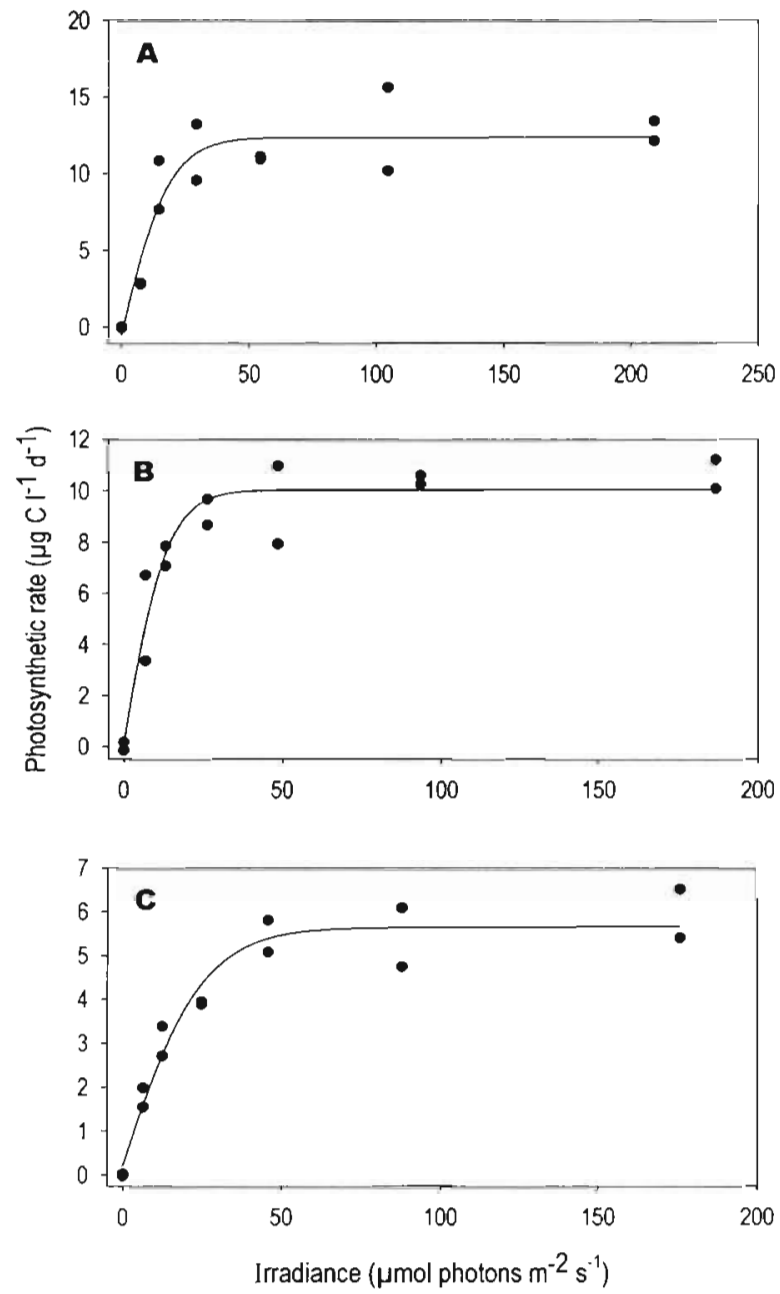

Fig. 4. Daily photosynthesis versus irradiance for in situ and simulated in situ brine incubations started on (A) 4 January, (B) 9 January, and (C) 17 January 1996. Curve fitting with hyperbolic tangent function (Jassby \& Platt 1976)

November and early December (Table 3), coincident with dinoflagellate and chrysoflagellate blooms in the sea ice at this site (Stoecker et al. 1998). Chl a values dropped dramatically between 4 and 14 December, coincident with formation of non-motile stages and cysts. After 14 December, much of the color on filters was not extracted in $90 \%$ acetone with grinding (authors' unpubl. obs.), indicating that the chlorophyll contained in resting stages probably was not extracted. Thus, chl a values probably reflect the biomass of photosynthetically active life history stages.

During December, estimates of $P_{\max }$ ranged from $\sim 19$ to $218 \mu \mathrm{g} \mathrm{Cl}^{-1}$ of brine $\mathrm{d}^{-1}$ (Table 3), which was higher than the 4.3 to 11.3 range of $P_{\max }$ for brine from the snow-covered Hut site (Stoecker et al. 1997). In both cases $P_{\max }$ should approximate in situ photosynthetic performance. 
There were large differences in photosynthetic performance between the 2 sites in December 1995. The primary difference between the ice environment at the sites was age of the ice and snow cover. The Hut site was on second year ice and the Inaccessible Island site

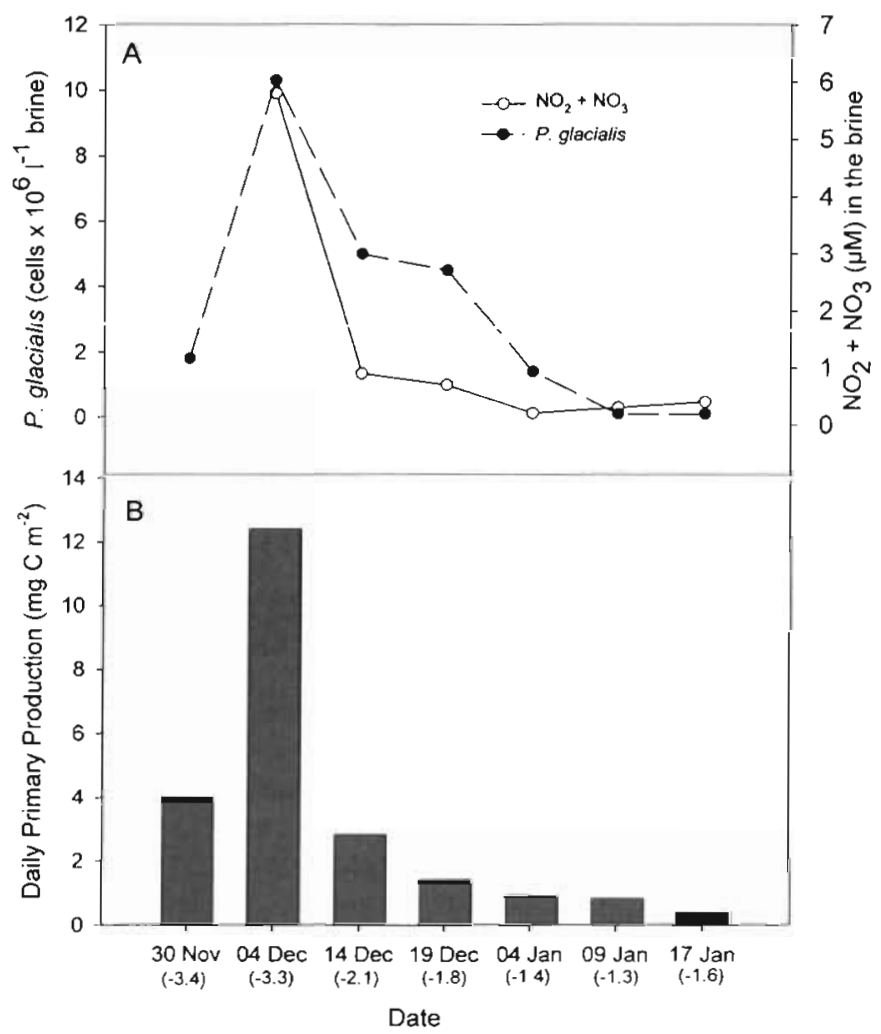

Fig. 5. Inaccessible Island site on snow-free first year sea-ice, spring-summer 1995-1996: (A) Abundance of Polarella glacialis (vegetative cells) and nitrate + nitrite concentrations in the brine; hypnozygotes (resting cysts) of $P$. glacialis were first noticed on 14 December 1995. (B) Estinated primary production in the upper $50 \mathrm{~cm}$ of sea-ice; brine temperatures in the upper sea ice are given in parentheses under each date was first year ice. Multi-year ice is usually depleted in inorganic nutrients compared to first year ice and is usually thicker (Dieckmann et al. 1991, Gleitz et al 1995). At the beginning of December, nitrate plus nitrite levels were high in the brine at both sites (Table 2 in Stoecker et al. 1997. Table 1 herein) and thus, in our case, nutrients do not appear to be the major cause of differences in productivity.

At the Hut site, the heavy snow cover $(27$ to $32 \mathrm{~cm}$ ) and ice thickness ( $\geq 2 \mathrm{~m}$ ) (Stoecker et al. 1997) made the upper ice a very different habitat than at the Inaccessible Island site, where the ice was $<2 \mathrm{~m}$ thick, wind-swept and almost devoid of snow cover (Stoecker et al. 1998). At the Hut site, brine temperatures in the upper ice during December remained $<-5^{\circ} \mathrm{C}$, brine salinity remained $>99$, and maximum irradiance. in the upper ice brine was $<40 \mu \mathrm{mol}$ photons $\mathrm{m}^{-2} \mathrm{~s}^{-1}$. At the Inaccessible Island site, conditions in the upper ice were much less extreme in terms of temperature and brine salinity. At least 6 times as much light reached the brine assemblages in the upper ice at this site than at the Hut site (Stoecker et al. 1998 and Tables 1 \& 3 herein). Dinoflagellates were much less abundant in brine at the Hut site than at the Inaccessible Island site, although chrysoflagellates and small diatoms were more abundant at the Hut site (Stoecker et al. 1998 and Table 2 herein). Due to higher ice temperatures at the snow-free site during December, brine volumes were about twice those at the Hut site. The lack of snow cover at the Inaccessible Island site made it a better habitat for growth of dinoflagellates and more productive than the Hut site. Previous studies have shown that snow cover has a dramatic impact on ice structure and its biota (reviewed in Gradinger et al. 1991, Ackley \& Sullivan 1994).

Differences between dates in incubation procedures, errors in deriving average irradiance and brine volume from measurements, and differences between the biology of collected brine and intact ice all may

Table 4. Comparison of estimated biomass $\left(\mu \mathrm{g} \mathrm{Cl}^{-1}\right)$ of phytoflagellates in the brine and in the upper $90 \mathrm{~cm}$ of the ice cores at the Inaccessible Island site. Biomass conversions and data for the cores from Stoecker et al. (1998). ND = no data

\begin{tabular}{|c|c|c|c|c|c|c|c|c|c|c|}
\hline \multirow[t]{2}{*}{ Date } & \multicolumn{2}{|c|}{ Chrysoflagellates } & \multicolumn{2}{|c|}{ Coccoid chrysophytes } & \multicolumn{2}{|c|}{ Polarelia glacialis ${ }^{\mathrm{a}}$} & \multicolumn{2}{|c|}{ Larger dinoflagellate } & \multicolumn{2}{|c|}{ Mantoniella sp } \\
\hline & Brine & Cores & Brine & Cores & Brine & Cores & Brine & Cores & Brine & Cores \\
\hline 27 Nov 95 & 113.2 & 2.9 & ND & ND & 80.8 & 99.4 & 35.9 & 175.7 & 5.0 & ND \\
\hline 4 Dec 95 & 101.8 & 126.6 & ND & ND & 464.1 & 154.9 & ND & 750.0 & ND & ND \\
\hline 14 Dec 95 & ND & 4.4 & 62.3 & 138.8 & 224.0 & 92.1 & 6.8 & 11.6 & 27.3 & 1.6 \\
\hline $19 \operatorname{Dec} 95$ & ND & 0.3 & 83 & 103.8 & 200.2 & 64.2 & 12.1 & 5.7 & 3.4 & 1.3 \\
\hline 27 Dec 95 & ND & 0.4 & 10.4 & 50.4 & 76.8 & 31.4 & ND & 2.8 & 2.5 & 1.9 \\
\hline 4 Jan 96 & ND & 0.1 & 6.2 & 11.4 & 61.4 & 19.0 & ND & 0.8 & 6.4 & 0.1 \\
\hline 9 Jan 96 & ND & ND & 3.8 & 1.4 & 5.5 & 3.7 & ND & ND & 10.8 & 1.9 \\
\hline 17 Jan 96 & ND & ND & 2.8 & 3.8 & 6.3 & 2.4 & ND & ND & 4.5 & 0.2 \\
\hline
\end{tabular}


have influenced our estimates of primary production in the upper ice. However, it is clear from our data that snow-free upper fast ice is an ecologically dynamic and productive habitat. There were large changes in daily primary production between late November and mid-January (Fig. 5). The highest algal biomass and production were in late November and early December, when the ice surface was still very cold and the brine hypersaline (Tables 1 to 3 ). These peaks in biomass and production coincided with peaks in the population of Polarella glacialis (Table 2), which excysts in the ice during the austral spring while ice temperature is still low and brine salinity is high (Stoecker et al. 1997). Biomass and production were relatively low during late December and January, although environmental conditions were more moderate at this time.

Declines in $P_{\max }$ but not chlorophyll-specific $P_{\max }$ between 4 and 14 December coincided with encystment of photosynthetic dinoflagellates and chrysoflagellates and with a drastic decline in inorganic nutrients in the brine (Table 1) and ice (Stoecker et al. 1998). Resting cysts usually are not photosynthetically active and we found that their chlorophyll was not readily extracted. Thus, reductions in $P_{\max }$ on 14 December were probably due to reductions in photosynthetically active biomass rather than to declines in chlorophyll-specific photosynthesis.

Nutrient depletion is a common trigger for sexuality and resting cyst formation in dinoflagellates (Pfiester \& Anderson 1987). The in situ cyst formation experiments indicated that nutrient depletion, rather than changes in temperature, salinity or irrradiance, triggered encystment of Polarella glacialis (Fig. 1). Laboratory experiments have confirmed that nutrient depletion, particularly inorganic nitrogen, is the primary stimulus for sexuality and cyst formation in this dinoflagellate (M.M.D.B. \& D.K.S. unpubl. data). However, nutrient depletion did not trigger statocyst formation (Fig. 2). Chrysophytes often exhibit densitydependent control of sexuality and statocyst formation (Sandgren 1988), which may explain why statocyst densities were as high or higher in nutrient-amended treatments as in controls. It is interesting that declining nutrient levels apparently triggered sexuality and encystment in the dinoflagellates before community chlorophyll-specific rates of photosynthesis were affected.

The estimated carbon content of vegetative cells of Polarella glacialis, chrysoflagellates, and Mantoniella sp. are 45,10, and $5 \mathrm{pg} \mathrm{cell}{ }^{-1}$, respectively (Stoecker et al. 1998). Although P. glacialis, chrysophytes and Mantoniella sp. occurred at roughly similar cell densities in December (Table 2), the dinoflagellate dominated biomass. Chl $a$ and $P_{\text {max }}$ declined before chlorophyllspecific $P_{\max }$, suggesting that cyst formation by the dinoflagellate, triggered by declining nutrients, reduced photosynthetically active biomass (indicated by chl a). Thus cyst formation may have been an important factor in the drastic reduction in primary production in the upper sea ice during early December. After 14 December, chlorophyll-specific $P_{\max }$ decreased sharply (Table 3) and nutrient levels declined further (Table 1). Reductions in photosynthetic performance due to nutrient stress (Gleitz et al. 1995) were undoubtedly important after 14 December.

In late December and January, inorganic nutrient concentrations remained low but fluctuated; this may have been due to a combination of nutrient regeneration within the ice and exchanges with the water column as brine drainage occurred and the ice decayed (Ackley \& Sullivan 1994, Gleitz et al. 1995). In early to mid-January, a small bloom of pennate diatoms and prasinophytes occurred in the upper sea ice (Stoecker et al. 1998) and in the brine (Table 2). Light-saturated rates of photosynthesis per unit brine volume were low during the diatom and prasinophyte blooms (Table 3).

Our data indicate an average daily production of $3.24 \mathrm{mg} \mathrm{C} \mathrm{m}^{-2}$ in the upper $50 \mathrm{~cm}$ of sea ice at the snow-free Inaccessible Island site of our investigation (Fig. 5). If we assume an 8 wk growing period (i.e., significant production occurred a week before our first experiment in which production was already relatively high) (Fig. 5), the estimated seasonal production in the upper $50 \mathrm{~cm}$ of sea ice is $-181 \mathrm{mg} \mathrm{C} \mathrm{m}^{-2}$. This probably underestimates production in the sea ice interior because as the ice warms in December and January, brine volumes increase and microalgae are found to $\geq 90 \mathrm{~cm}$ depth (Stoecker et al. 1998). Earlier we reported seasonal changes in biomass of phytoflagellates in ice cores from the Inaccessible Island site (Stoecker et al. 1998). On 14 November 1995, the total phytoflagellate biomass was near zero. The maximum biomass that developed in the upper ice of vegetative

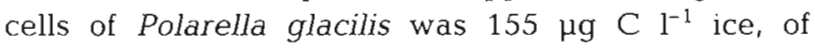
chrysoflagellates was $127 \mu \mathrm{g} \mathrm{C}^{-1}$ ice and of prasinophytes was $2 \mu \mathrm{g} \mathrm{C} \mathrm{l}^{-1}$ ice (diatom biomass was not calculated). These data indicate algal production of at least $256 \mathrm{mg} \mathrm{C} \mathrm{m}^{-2}$. The production estimate based on biomass is higher than the estimate based on ${ }^{14} \mathrm{C}$ uptake because it includes a greater depth of ice. Another factor that may contribute to the higher estimate based on biomass than primary productivity is the nutrition of phytoflagellates. Many dinoflagellates and chrysophytes are mixotrophs (Holen \& Boraas 1995, Stoecker 1999), and thus it is possible that the phytoplankton biomass is partially supported by carbon from sources other than photosynthesis.

Production may occur during seasons not included in our study. Fritsen et al. (1994) observed an autumn bloom of sea ice algae within the upper layer of multi- 
year pack ice. The bloom was driven by exchange of nutrient-depleted brine with nutrient-rich seawater as temperatures in the upper ice declined. Infiltration of seawater into the upper ice due to snow loading can also provide new nutrients and increase production (Ackley \& Sullivan 1994). We don't know if primary productivity decreased or increased in the ice after it broke out. Estimates of production based only on austral spring and early summer are almost certainly underestimates of yearly production for a patch of ice.

Our estimates of primary production in the upper sea ice interior at a snow-free site are at least twice as high as an estimate of average microalgal production for interior sea ice assemblages $\left(80 \mathrm{mg} \mathrm{C} \mathrm{m}^{-2}\right)$ in the Antarctic (Table 1 in Legendre et al. 1992). Our estimate of production for the upper ice inierios is lúwer thañ estimates of production by surface, freeboard and bottom assemblages from the Antarctic $(4000$ to $32000 \mathrm{mg} \mathrm{C}$ $\mathrm{m}^{-2}$ ) (Table 1 in Legendre et al. 1992). However, it is difficult to evaluate the contribution of upper ice brine assemblages to total production in the Antarctic for several reasons. This habitat and its algal assemblages are often poorly defined in the literature (Horner et al. 1992). Chlorophyl must underestimate biomass in the upper ice relative to base of the ice because the upper ice is usually a colder, higher irradiance environment than the base of the ice (Kottmeier \& Sullivan 1988, Arrigo et al. 1991). C:chl a ratio decreases with increases in irradiance and decreases in temperature (Geider et al. 1997). In the upper sea ice, production estimates based on standing stock of chlorophyll may considerably underestimate true production. Most field studies have not included primary production in the upper sea ice interior, particularly during austral spring, when upper ice temperature is low and brine salinity is high, but when these assemblages are most productive. Often it has been assumed that conditions are too harsh for the growth of microalgae in the upper sea ice interior early in the season (Kottmeier \& Sullivan 1988).

There are large differences in the geophysics and biology of fast and pack ice. Both environments are extremely heterogeneous (Garrison et al. 1986, Ackley \& Sullivan 1994). Year-to-year variation in the formation and decay of sea ice contributes to the problem of estimating the spatial extent of different sea ice assemblages and their productivity. For these reasons, it is not currently possible to determine the contribution of upper sea ice interior habitats to sea ice primary production. However, recent studies in the Arctic and Antarctic suggest that upper surface and interior sea ice assemblages, including those dominated by phytoflagellates, may make an important contribution to sea ice primary production, sometimes equaling or exceeding production by algae growing at the base of the sea ice (Mock \& Gradinger 1999).
Acknowledgements. We thank Antarctic Support Associates for scientific support, the US Coast Guard and New Zealand Air Force for logistical support, Biospherical Instruments for daily radiance data, Dr K. R. Arrigo for advice and assistance in modeling the irradiance data, and $\mathrm{Dr} W$. J. Henley for advice on $P$ - $I$ curve-fitting. Comments of anonymous reviewers and of Dr W. J. Henley improved the manuscript. This work was supported by a grant from the National Science Foundation, OPP-9318772. UMCES contribution no. 3334

\section{LITERATURE CITED}

Ackley SF, Sullivan CW (1994) Physical controls on the development and characteristics of Antarctic sea ice biological communities - a review and synthesis. Deep-Sea Res. 41 : $1583-1604$

Ackley SF, Buck KR, Taguchi S (1979) Standing crop of algae in the sea ice of the Weddell Sea region. Deep-Sea Res 26A:269-281

Archer SD, Leakey RJG, Burkill PH, Sleigh MA, Appleby CJ (1996) Microbial ecology of sea ice at a coastal Antarctic site: community composition, biomass and temporal change. Mar Ecol Prog Ser 135:179-195

Arrigo KR, Sullivan CW, Kremer JN (1991) A bio-optical model of Antarctic sea ice. J Geophys Res 96:10581-10592

Arrigo KR, Dieckmann G, Gosselin M, Robinson DH, Fritsen

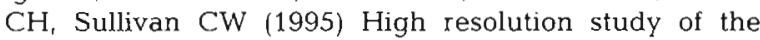
platelet ice ecosystem in McMurdo Sound, Antarctica:biomass, nutrient, and production profiles within a dense microalgal bloom. Mar Ecol Prog Ser 127:255-268

Arrigo KR, Worthen DL, Lizotte MP, Dixon P, Dieckmann G (1997) Primary production in Antarctic sea ice. Science 276:394-397

Arrigo KR, Worthen DL, Dixon P, Lizotte MP (1998) Primary productivity of near surface communities within Antarctic pack ice. In: Arrigo KA, Lizotte MP (eds) Antarctic sea ice biological processes, interactions, and variability. American Geophysical Union, Washington, DC, p 23-43

Buck KR, Nielsen TG, Hansen BW, Gastrup-Hansen D, Thomsen HA (1998) Infiltration phyto- and protozooplankton assemblages in the annual sea ice of Disko Island, West Greenland, spring 1996. Polar Biol 20:377-381

Dieckmann GS, Lange MA, Ackley SF, Jennings JC Jr (1991) The nutrient status in sea ice of the Weddell Sea during winter: effects of sea ice texture and algae. Polar Biol 11: $449-456$

Fritsen CH, Lytle VI, Ackley SF, Sullivan CW (1994) Autumn bloom of Antarctic pack-ice algae. Science 266:782-784

Garrison DL, Buck KR (1989) The biota of Antarctic pack ice in the Weddell Sea and Antarctic Peninsula regions. Polar Biol 10:211-219

Garrison DL, Buck KR (1991) Surface-layer sea ice assemblages in Antarctic pack ice during the austral spring: environmental conditions, primary production and community structure. Mar Ecol Prog Ser 75:161-172

Garrison DL, Sullivan CW, Ackley SF (1986) Sea ice microbial communities in Antarctica. Bioscience 36:243-250

Geider RJ, MacIntyre HI, Kana TM (1997) Dynamic model of phytoplankton growth and acclimation: responses of the balanced growth rate and the chlorophyll a:carbon ratio to light, nutrient-limitation and temperature. Mar Ecol Prog Ser 148:187-200

Gleitz M, Kirst GO (1991) Photosynthesis-irradiance relationships and carbon metabolism of different ice algal assemblages collected from Weddell Sea pack ice during austral spring (EPOS 1). Polar Biol 11:385-392 
Gleitz $M$, van der Loeff MR, Thomas DN, Dieckmann GS, Millero FJ (1995) Comparison of summer and winter inorganic carbon, oxygen and nutrient concentrations in Antarctic sea ice brine. Mar Chem 51:81-91

Gradinger R, Spindler M, Henschel D (1991) Development of Arctic sea-ice organisms under graded snow cover. In: Sakshaug E, Hopkins CCE, Øritsland NA (eds) Proceedings of the Pro Mare symposium on polar marine ecology, Trondheim, 12-16 May 1990. Polar Res 10:295-307

Gradinger R, Spindler M, Weissenberger J (1992) On the structure and development of Arctic pack ice communities in Fram Strait: a multivariate approach. Polar Biol 12: $727-733$

Henley WJ (1993) Measurement and interpretation of photosynthesis light-response curves in algae in the context of photoinhibition and diel changes. J Phycol 29:729-739

Holen DA, Boraas ME (1995) Mixotrophy in chrysophytes. In: Sandgren CD, Smol JP, Kristiansen J (eds) Chrysophyte algae. Cambridge University Press, Cambridge, p 119-140

Horner R, Ackley SF, Dieckmann GS, Gulliksen B, Hoshiai T, Legendre L, Melnikov IA, Reeburgh WS, Spindler M, Sullivan CW (1992) Ecology of sea ice biota. 1. Habitat, terminology, and methodology. Polar Biol 12:417-427

Hsiao SIC (1980) Quantitative composition, distribution, community structure and standing stock of sea ice microalgae in the Canadian Arctic. Arctic 33:768--793

Ikävalko J, Gradinger R (1997) Flagellates and heliozoans in the Greenland Sea ice studied live using light microscopy. Polar Biol 17:473-481

Jassby AD, Platt T (1976) Mathematical formulation of the relationship between photosynthesis and light for phytoplankton. Limnol Oceanogr 21:540-547

Kirst GO, Wiencke C (1995) Ecophysiology of polar algae. J Phycol 31:181-199

Kottmeier ST, Sullivan CW (1988) Sea ice microbial communities (SIMCO). 9. Effects of temperature and salinity on rates of metabolism and growth of autotrophs and heterotrophs. Polar Biol 8:293-304

Legendre L, Ackley SF, Dieckmann GS, Gulliksen B, Horner R, Hoshiai T, Melnikov IA, Reeburgh WS, Splinder M, Sullivan CW (1992) Ecology of sea ice biota. 2. Global significance. Polar Biol 12:429-444

Lizotte MP, Sullivan CW (1991) Photosynthesis-irradiance relationships in microalgae associated with Antarctic pack ice: evidence for in situ activity. Mar Ecol Prog Ser 71: 175-184

Lizotte MP, Sullivan CW (1992) Photosynthetic capacity in microalgae associated with Antarctic pack ice. Polar Biol $12: 497-502$

Maykut GA (1985) The ice environment. In: Horner RA (ed) Sea ice biota. CRC Press, Boca Raton, FL, p 21-82

McConville MJ, Wetherbee R (1983) The bottom-ice microalgal community from annual ice in the inshore waters of east Antarctica. J Phycol 19:431-439

Mock T, Gradinger R (1999) Determination of Arctic ice algal production with a new in situ incubation technique. Mar Ecol Prog Ser 177:15-26

Montresor M, Procaccini G, Stoecker DK (1999) Polarella glacialis gen. nov., sp. nov. (Dinophyceae): Suessiaceae are still alive! J Phycol 35:186-197

Palmisano AC, Sullivan CW (1983) Sea ice microbial commu-

Editorial responsibility: Patricia Glibert,

Cambridge, Maryland, USA nities (SIMCO). I. Distribution, abundance, and primary production of ice microalgae in McMurdo Sound, Antarctica in 1980. Polar Biol 2:171-177

Parsons TR, Maita Y, Lalli CM (1984) A manual of chemical and biological methods for seawater analyses. Pergamon Press, Oxford

Pfiester LA, Anderson DM (1987) Dinoflagellate reproduction. In: Taylor FJR (ed) The biology of dinoflagellates. Botanical monographs, Vol 21. Blackwell Scientific Publications, Oxford, p 611-648

Rand JH, Mellor M (1985) Ice-coring augers for shallow depth sampling. Dept of the Army, Cold Regions Research and Engineering Laboratory, Corps of Engineers, Publ 85-21. Hanover, NH

Robinson DH, Kolber Z, Sullivan CW (1997) Photophysiology and photoacclimation in surface sea ice algae from McMurdo Sound, Antarctica. Mar Ecol Prog Ser 147: 243-256

Sandgren CD (1988) The ecology of chrysophyte flagellates: their growth and perennation strategies as freshwater phytoplankton. In: Sandgren CD (ed) Growth and reproductive strategies of freshwater phytoplankton. Cambridge University Press, Cambridge, p 9-104

Sokal RR, Rohlf FJ (1995) Biometry, 3rd edn. WH Freeman and $\mathrm{Co}$, New York

Stoecker DK (1999) Mixotrophy among dinoflagellates. J Eukaryot Microbiol 46:397-401

Stoecker DK, Buck KR, Putt M (1992) Changes in the sea-ice brine community during the spring-summer transition, McMurdo Sound, Antarctica. I. Photosynthetic protists. Mar Ecol Prog Ser 84:265-278

Stoecker DK, Gustafson DE, Merrell JR, Black MMD, Baier CT (1997) Excystment and growth of chrysophytes and dinoflagellates at low temperatures and high salinities in Antarctic sea-ice. J Phycol 33:585-595

Stoecker DK, Gustafson DE, Black MMD, Baier CT (1998) Population dynamics of microalgae in the upper land-fast sea ice at a snow-free location. J Phycol 34:60-69

Syvertsen EE, Kristiansen S (1993) Ice algae during EPOS, leg 1: assemblages, biomass, origin and nutrients. Polar Biol 13:61-65

Watanabe K, Satoh H, Hoshiai T (1990) Seasonal variation in ice algal assemblages in the fast ice near Syowa Station in 1983/84. In: Kerry KR, Hempel G (eds) Antarctic ecosystems. Ecological change and conservation. Springer-Verlag, Berlin, p 136-142

Weeks WF, Ackley SF (1982) The growth, structure and properties of sea ice. Dept of the Army, Cold Regions Research and Engineering Laboratory, Corps of Engineers, Monogr 82-1, Hanover, NH

Weissenberger J, Dieckmann G, Gradinger R, Spindler M (1992) Sea-ice: a cast technique to examine and analyze brine pockets and channel structure. Limnol Oceanogr 37 : 179-183

Welschmeyer NA, Lorenzen CJ (1984) Carbon-14 labeling of phytoplankton carbon and chlorophyll a carbon: determination of specific growth rates. Limnol Oceanogr 29: 135-145

Wheeler PA, Gosselin M, Sherr E, Thibault D, Kirchman DL, Benner, R, Whitledge TE (1996) Active cycling of organic carbon in the central Arctic Ocean. Nature 380:697-699

Submitted: December 28, 1998; Accepted: April 15, 2000

Proofs received from author(s): June 6, 2000 